Tropical Journal of Pharmaceutical Research February 2012; 11 (1): 91-98

(C) Pharmacotherapy Group, Faculty of Pharmacy, University of Benin,

Benin City, 300001 Nigeria.

All rights reserved.

\title{
Development and Application of Ligand-Exchange Reaction Method for the Determination of Clonazepam
}

\section{Snežana S Mitić, Aleksandra N Pavlović*, Snežana B Tošić, Emilija T Pecev, Milan N Mitić and Milan B Stojković}

University of Niš, Faculty of Sciences and Mathematics, Department of Chemistry, Višegradska 33, P.O.Box 224, 18000 Niš, Serbia

\begin{abstract}
Purpose: This paper presents an improved kinetic-spectrophotometric procedure for determining clonazepam (CZP) in pharmaceutical formulations and human serum.

Methods: The method is based on ligand-exchange reaction. The reaction was followed spectrophotometrically by measuring the rate of change of absorbance at $425 \mathrm{~nm}$ in ethanolic sodium hydroxide solution.

Results: The optimum operating conditions for reagent concentrations and temperature were established. Linear calibration curve was obtained in the range of $0.32-4.10 \mu \mathrm{g} \mathrm{m}^{-1}$. The optimized conditions yielded a theoretical detection limit of $0.24 \mu \mathrm{g} \mathrm{mL}^{-1}$ based on the $3.3 S_{0}$ criterion, where $S_{0}$ is standard deviation of the calibration line. The interference of certain drugs, foreign ions and amino acids on the reaction rate were studied in order to assess the selectivity of the method.

Conclusion: The developed method is sensitive, accurate and reproducible and could be used for routine anlysis of clonazepam in pharmaceutical preparations and serum samples.
\end{abstract}

Keywords: Clonazepam, Ligand-exchange reaction, Kinetic spectrometry, Validation, Pharmaceutical preparation, Human serum 


\section{INTRODUCTION}

Clonazepam is an anticonvulsant agent widely used in the treatment of epilepsy in adults and children [1]. As a result of the therapeutic importance and widespread use of this compound, the literature contains many reports dealing with its determination. For the biopharmacological, clinical and toxicological studies of these drugs, a rapid, sensitive and selective analytical method for its determination is essential.

The British Pharmacopoeia [2] recommends non-aqueous titration with perchloric acid for the determination of clonazepam. For dosage forms, high-pressure liquid chromatography (HPLC) is recommended by US Pharmacopoeia [3]. Several methods for the assay of this compound have been reported by many authors, e.g., spectrometric methods [4-6], potentiometric methods $[7,8]$, voltammetry [9], polarography [10], HPLC [10-12], gas chromatography coupled with mass spectrometry (GC-MS) [11,13].

The present work describes a kinetic method for the determination of clonazepam (CZP) in commercial pharmaceutical preparations and human serum. The method is based on ligand-exchange reaction. This type of reactions is recent and has not been studied much. The procedure is easier to execute, does not need sophisticated instruments or special skill, and requires less sample handling than methods currently described in the literature.

\section{EXPERIMENTAL}

\section{Apparatus}

Perkin-Elmer Lambda $15 \quad$ UV/Vis spectrophotometer equipped with kinetic accessory provided with a temperature controlled cell. A model 1200 Agilent Technologies was used for HPLC analysis. The analytical column was $\mathrm{C}_{18}$ (Zorbax, $5 \mu \mathrm{m}$, $250 \times 4.6 \mathrm{~mm}$ ).

\section{Reagents}

Stock solution $\left(1.0 \times 10^{-3} \mathrm{~mol} \mathrm{~L}^{-1}\right)$ of clonazepam was prepared in absolute ethanol from clonazepam powder (certified purity: $99.92 \%$ ), kindly provided by Galenika, a.d., Belgrade, Serbia. The solution was stored at $4 \stackrel{\circ}{\circ}$. Analytical reagent grade chemicals and deionised water (MicroMed high purity water system, TKA Wasseraufbereitungssysteme $\mathrm{GmbH}$ ) were used for the preparation of all solutions. Sodium hydroxide solution $\left(\mathrm{NaOH}, 1.0 \mathrm{~mol} \mathrm{~L}^{-}\right.$ $\left.{ }^{1}\right)$ was prepared from $\mathrm{NaOH}$ (Merck). 1nitroso-2-naphthol solution $\left(1.0 \times 10^{-3} \mathrm{~mol} \mathrm{~L}^{-1}\right)$ (Merck) was prepared by dissolving a known amount $(0.0086 \mathrm{~g})$ of this reagent in $5 \mathrm{ml}$ absolute ethanol and diluting it with water (total volume $50 \mathrm{~mL}$ ).

Stock solution of cobalt(II) $\left(1.7 \times 10^{-3} \mathrm{~mol} \mathrm{~L}^{-1}\right)$ was prepared by dissolving $\mathrm{CoCl}_{2} \cdot 6 \mathrm{H}_{2} \mathrm{O}$ (Merck) in water. A working solution $\left(1.7 \times 10^{-4}\right.$ mol $\mathrm{L}^{-1}$ ) was obtained by appropriately diluting the stock cobalt solution with water. The ionic strength of the reaction mixture was kept constant at 0.1 by adding to the mixture an appropriate volume of $\mathrm{NaCl}$ solution (1 $\mathrm{mol} \mathrm{L}^{-1}$ ).

All the glassware used were washed with aqueous $\mathrm{HCl}(1: 1)$ and then thoroughly rinsed with running, distilled water, and then finally with deionised water.

\section{General procedure}

In order to obtain good mechanical and thermal stability, the instruments were run for $10 \mathrm{~min}$ prior to the first measurement. The reaction was carried out as follows. In the reaction - mixture vessel with four compartments, the solution of 1-nitroso-2naphthol was placed in one compartment, sodium hydroxide in the second, clonazepam in the third, cobalt(II), electrolyte for ionic strength and ethanol (total volume: $10 \mathrm{~mL}$ ) in the fourth compartment.

The vessel was thermostated at $22.00 \pm 0.02$ ${ }^{\circ} \mathrm{C}$ and the reaction was initiated by 
vigorously shaking the reactants. The reaction solution was transferred to a cell, and the absorbance at $425 \mathrm{~nm}$ was measured spectrophotometrically every $30 \mathrm{~s}$ over a period of 5 - 6 min (after mixing) against the reagent blank prepared similarly. The rate of the reaction $(d c / d t)$ at different concentrations of each of the reactants was obtained by measuring the slope of the linear part of the kinetic curves to the absorbancetime plot (from Beer's law):

$$
\begin{array}{ll}
A=\varepsilon \cdot l \cdot c, & d A / d t=\varepsilon \cdot l \cdot d c / d t, \\
d c / d t=\frac{d A / d t}{\varepsilon \cdot l}, & \text { slope } \equiv \text { rate }=d A / d t .
\end{array}
$$

The calibration graph was constructed by plotting the slope of the linear part of the kinetic curve versus the concentration of CZP $\left(c_{C Z P}, \mu \mathrm{g} \mathrm{mL} \mathrm{L}^{-1}\right)$.

\section{Procedure for tablets}

A total of twenty tablets of each of different pharmaceutical formulations containing CZP were weighed and finely powdered using a mortar and pestle. An accurately weighed portion of the resulting powder, equivalent to $2 \mathrm{mg}$ of CZP, was dissolved in $25 \mathrm{~mL}$ of ethanol. The mixture was centrifuged at 3500 rpm for $5 \mathrm{~min}$, filtered through a $0.45 \mu \mathrm{m}$ membrane filter (Millipore) directly into a 50 $\mathrm{mL}$ volumetric flask and made up to volume with ethanol to obtain a solution of theoretical CZP concentration of $40.0 \mu \mathrm{g} \mathrm{mL}^{-1}$. Aliquots of this solution were transferred into vessels spanning the concentration range listed in Table 4. In all cases, it was assumed that the actual content of the tablet corresponds to the labelled strength of the products.

\section{Serum sample preparation}

Human lyophilised serum (Lyotrol N) was used. The serum sample was spiked at one concentration level listed in Table 5. To 0.5 $\mathrm{mL}$ of serum, the appropriate amount of the stock solution of CZP $\left(1.0 \mathrm{mg} \mathrm{mL}^{-1}\right)$ and 25 $\mathrm{mL}$ of ethanol was added; after brief vortex mixing, it was centrifuged for $5 \mathrm{~min}$ at 3000 $\mathrm{rpm}$ to separate the protein precipitate. The supernatant was collected in a $50 \mathrm{~mL}$ standard volumetric flask and filled up to the mark with the same solvent. The serum sample contained $200.0 \mu \mathrm{g} \mathrm{mL}^{-1}$ of CZP. Aliquots of this solution were transferred into vessels spanning the concentration range listed in Table 5. For kinetic determination, $\mathrm{Fe}^{3+}$ ions were masked by adding the appropriate amount of fluorine $\left(\mathrm{F}^{-}\right)$ions $\left(1 \times 10^{-4} \mathrm{~g} \mathrm{~mL}^{-1}\right)$. For HPLC determination, aliquots of CZP solution were transferred to a $10 \mathrm{~mL}$ volumetric flask, evaporated to dryness in a water bath, the residue reconstituted with mobile phase, and then 10 $\mu \mathrm{L}$ transferred to a glass vial for automatic injection into the HPLC system.

\section{Comparative method}

HPLC method [2] was used for accuracy evaluation. Clonazepam was detected and quantified on a $250 \times 4.6 \mathrm{~mm}$ Zorbax $\mathrm{C}_{18}$ $(5 \mu \mathrm{m})$ analytical column operating at room temperature. The mobile phase was a mixture of tetrahydrofuran-methanol-water, 10:42:48 (v/v/v)). The eluate was monitored at $254 \mathrm{~nm}$. Injection of the samples $(10 \mu \mathrm{L})$ was performed using an autosampler. Flow rate was $1 \mathrm{~mL} \mathrm{~min}^{-1}$.

\section{Statistical analysis}

Data were reported as mean \pm standard deviation (SD) for five determinations. Statistical analysis was performed by Student t-test and F-test at $95 \%$ confidence level, using a statistical package (Statistica 8.0, StatSoft, Inc, Tulsa, OK, USA).

\section{RESULTS}

\section{Mechanism of the reaction}

Clonazepam shows complexing ability with Co(II) [14]. The complex agrees with the formula $\mathrm{Co}_{3}(\mathrm{CZP})_{2}$. Its cobalt complex chelate is more stable than that formed with $\mathrm{R}(\mathrm{NO}) \mathrm{OH}$ and the equilibrium of the reaction moves towards the formation of this complex 
. CZP was determined by monitoring the rate of appearance of 1-nitroso-2-naphthol in basic medium at $425 \mathrm{~nm}$.

$3 \mathrm{Co}\left[\mathrm{R}(\mathrm{NO}) \mathrm{O}_{2} \cdot 2 \mathrm{H}_{2} \mathrm{O}+2 \mathrm{CZP} \rightarrow \mathrm{Co}_{3}[\mathrm{CZP}]_{2}+6 \mathrm{R}(\mathrm{NO}) \mathrm{OH}\right.$

Thus by measuring the absorbance change of the reaction mixture at the $\mathrm{R}(\mathrm{NO}) \mathrm{OH}$ maximum wavelength $(\lambda=425 \mathrm{~nm})$ the concentration of CZP can be measured according to a calibration graph. The plot of the reaction rate as a function of the clonazepam concentration is a straight line which can be used as a calibration graph.

\section{Kinetic studies}

A tangent method was used for processing the kinetic data. The rate of the reaction $(d c / d t)$ at different concentrations of each of the reactants was obtained by measuring the slope of the linear part of the kinetic curves to the absorbance-time plot $\left(d c / d t=\frac{d A / d t}{\varepsilon \cdot l}\right.$, slope $\left.=\mathrm{dA} / \mathrm{dt}\right)$.

\section{Effect of variables}

In order to find the optimum experimental conditions for the determination of clonazepam, the kinetics of the indicator reaction proposed was studied.

The dependence of the reaction rate on the alkalinity of the solution examined in the range of $2.0-12.0 \times 10^{-2} \mathrm{~mol} \mathrm{~L}^{-1}$ became constant when the concentration of sodium hydroxide was above $6.0 \times 10^{-2} \mathrm{~mol} \mathrm{~L}^{-1}$. A sodium hydroxide concentration of $8.0 \times 10^{-2}$ $\mathrm{mol} \mathrm{L}^{-1}$ was, therefore, selected for further work.

The effect of the concentration of 1-nitroso-2naphthol on the rate of reaction was studied in the range $0.2-1.8 \times 10^{-5} \mathrm{~mol} \mathrm{~L}^{-1}$. The reaction rate increased linearly with increase in $\mathrm{R}(\mathrm{NO}) \mathrm{OH}$ concentration up to $1.2 \times 10^{-5}$ $\mathrm{mol} \mathrm{L}^{-1}$; beyond this concentration, up to 1.8 $\times 10^{-5} \mathrm{~mol} \mathrm{~L}^{-1} \mathrm{R}(\mathrm{NO}) \mathrm{OH}$, the rate remained constant. Thus, a concentration of $1.4 \times 10^{-5}$ mol $L^{-1}$ was selected as optimal for further investigation.

The influence of the concentration of $\mathrm{Co}$ (II) on the rate of reaction examined in the range of $0.3-4.4 \times 10^{-5} \mathrm{~mol} \mathrm{~L}^{-1}$. The reaction rate increased with increasing concentration of $\mathrm{Co}$ (II) and became constant at $2.4 \times 10^{-5} \mathrm{~mol}$ $\mathrm{L}^{-1}$ and above. Co(II) concentration of $3.1 \times 10^{-}$ $5 \mathrm{~mol} \mathrm{~L}^{-1}$ was recommended for the determination process.

The effect of temperature on the reaction rate was studied in the range $19-31{ }^{\circ} \mathrm{C}$. The absorbance-time curves obtained at these temperatures indicated the temperature dependence of the reaction rate. The rate for different concentrations of CZP at each temperature was calculated and utilized for plotting the calibration curve ( slope $\equiv$ rate $=d A / d t$ ). It was found that the calibration graph obtained at $22{ }^{\circ} \mathrm{C}$ possessed good linearity and it was recommended that the determination can be carried out at $22^{\circ} \mathrm{C}$.

For the validation process, the following parameters were characterized [3]: linearity and range; limit of detection; repeatability; percent recoveries; precision; selectivity. The least squares equation [15] $(y=b x+a$, where $b$ and $a$ are slope and intercept, respectively) for the calibration graph and correlation coefficient $(r)$ for the determination of CZP in the interval 0.32 to $4.1 \mu \mathrm{g} \mathrm{mL}^{-1}$ under the optimal reaction conditions $\left(c_{R(\mathrm{NO}) \mathrm{OH}}=1.4 \times 10^{-5} \mathrm{~mol} \mathrm{~L}^{-1}, c_{\mathrm{NaOH}}=8.0 \times 10^{-2}\right.$

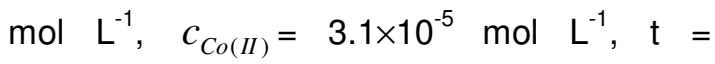
$22.00 \pm 0.02{ }^{\circ} \mathrm{C}$ ) were calculated:

$$
\text { slope } \cdot 10^{3}=0.75881 \cdot c_{C Z P}+0.93235
$$

$(r=0.9985)$

where slope is the slope of the linear part of the kinetic curve to the absorbance-time plot ( slope $=d A / d t=\varepsilon \cdot l \cdot d c / d t$, Beer's law $)$ and $c_{C Z P}$ is clonazepam concentration expressed in $\mu \mathrm{g} \mathrm{mL}^{-1}$. 
The variance $\left(S_{0}^{2}\right)$ of the calibration line was evaluated to be $1.3 \times 10^{-5}{\mu g^{2}}^{2} L^{-2}$. The quantitative parameters of the analysis are given in Table 1.

Table 1: Quantitative parameters of the analysis

\begin{tabular}{|c|c|}
\hline Parameter & Value \\
\hline $\begin{array}{l}\text { Calibration } \\
\text { range }\left(\mu g \mathrm{~mL}^{-1}\right)\end{array}$ & $0.32-4.1 \quad n=7$ \\
\hline $\begin{array}{l}\text { Regression } \\
\text { equation }\end{array}$ & $\operatorname{tg} \alpha \cdot 10^{3}=0.53509 \cdot c_{D Z P}+0.37589$ \\
\hline $\begin{array}{l}\text { (Slope } \\
\text { SD) } \times 10^{3}\end{array}$ & $0.76 \pm 0.02$ \\
\hline $\begin{array}{l}\text { (Intercept } \\
\text { SD }) \times 10^{3}\end{array}$ & $0.93 \pm 0.05$ \\
\hline $\begin{array}{l}\text { Correlation } \\
\text { coefficient, } r\end{array}$ & $r=0.9985$ \\
\hline Variance & $3.6 \times 10^{-3}$ \\
\hline $\begin{array}{l}\left(S_{0} \times 10^{3}\right)^{2} \\
\left(\mu \mathrm{mL}^{-1}\right)^{2}\end{array}$ & \\
\hline $\begin{array}{l}\text { Detection limit } \\
\left(\mu \mathrm{gL}^{-1}\right)\end{array}$ & 0.24 \\
\hline
\end{tabular}

The kinetic equation ( $\mathrm{Eq} 3$ ) for the reaction was deduced on the basis of the kinetics of the indicator reaction proposed.

$$
\begin{aligned}
& \text { rate }=k \cdot c_{\mathrm{NaOH}}^{0} \cdot c_{R(\mathrm{NO}) \mathrm{OH}}^{0} \cdot c_{\mathrm{Co}{ }^{2+}}^{0} \cdot c_{\mathrm{CZP}} \\
& \text { rate }=k \cdot c_{\mathrm{CZP}} \ldots \ldots \ldots \ldots \ldots \ldots \ldots \ldots \ldots \ldots \ldots \ldots \ldots \ldots \ldots \ldots \ldots \ldots \ldots \ldots \ldots \ldots \ldots \ldots
\end{aligned}
$$

where $\mathrm{k}$ is the constant proportional to the rate constant of the reaction. The equation is valid for the following concentrations: $\mathrm{R}(\mathrm{NO}) \mathrm{OH}(1.2-1.8) \times 10^{-5} \mathrm{~mol} \mathrm{~L}^{-1}, \mathrm{NaOH}(6.0-$ 12.0) $\times 10^{-2} \mathrm{~mol} \mathrm{~L}^{-1}, \mathrm{Co}(\mathrm{II})(2.4-4.4) \times 10^{-5} \mathrm{~mol} \mathrm{~L}^{-}$ ${ }^{1}, \mathrm{CZP} 0.32-4.1 \mu \mathrm{g} \mathrm{mL}^{-1}$.

The limit of detection (LOD) [16] was evaluated using Eq 4:

$$
L O D=3.3 \times S_{0} / b
$$

where $S_{0}$ is the residual standard deviation of the calibration line, $b$ is the slope of the calibration line (analytical sensitivity) and which was found to be $0.24 \mu \mathrm{g} \mathrm{mL}^{-1}$.

The precision and accuracy of the proposed method was studied by performing the experiment 5 times at three different concentration levels (low, medium and high) of clonazepam. The results are shown in Table 2.

\begin{tabular}{|c|c|c|c|}
\hline $\begin{array}{l}\text { Taken } \\
\left(\mu \mathrm{g} \mathrm{mL}^{-1}\right)\end{array}$ & $\begin{array}{l}\text { Found }^{(*)} \\
\bar{x} \pm \overline{S D} \\
\left(\mu \mathrm{g} \mathrm{mL}^{-1}\right)\end{array}$ & $\begin{array}{l}\text { RSD }^{(")} \\
(\%)\end{array}$ & $\begin{array}{l}\text { Recover } \\
\text { y } \\
\text { (\%) }\end{array}$ \\
\hline 0.32 & $0.33 \pm 0.01$ & 3.39 & 103.12 \\
\hline 2.21 & $2.15 \pm 0.04$ & 2.08 & 97.28 \\
\hline 4.1 & $3.99 \pm 0.06$ & 1.53 & 97.32 \\
\hline
\end{tabular}

Table 2: Accuracy and precision of the proposed method

The effect of temperature on reaction rate is well known and is important in understanding the various activation parameters of the reaction products. In order to evaluate the apparent activation parameters, the reaction rate was studied in the range $19-31{ }^{\circ} \mathrm{C}$ at $c_{\mathrm{NaOH}}=8.0 \times 10^{-2} \mathrm{~mol} \mathrm{~L}^{-1}, c_{R(\mathrm{NO}) \mathrm{OH}}=$ $1.4 \times 10^{-5} \mathrm{~mol} \mathrm{~L}^{-1}, \quad c_{C o(I I)}=3.1 \times 10^{-5} \mathrm{~mol} \mathrm{~L}^{-1}$, $c_{C Z P}=7.0 \times 10^{-6} \mathrm{~mol} \mathrm{~L}^{-1}$. Arrhenius curve was constructed by plotting log $k$ versus $1 / T$ and found to be linear with a coefficient of correlation, $r=0.9998$. Activation energy $(\mathrm{Ea})$ was calculated from the slope $(-\mathrm{Ea} / 2.303 \mathrm{R})$ and found to be $92.45 \pm 0.05 \mathrm{~kJ} \mathrm{~mol}^{-1}$.

\section{Interference studies}

To assess the selectivity of the method, a systematic study of the possible interferences by those species accompanying CZP in pharmaceuticals was carried out. The criterion of interference was fixed at $5 \%$ variation of the average slope change measured $(n=5)$ for the established level of clonazepam. The tolerance limits (expressed as $w / w$ ratio) for the species studied on the determination of $2.21 \mu \mathrm{g} \mathrm{mL}^{-1}$ of CZP are given in Table 3.

Trop J Pharm Res, February2012;11 (1): 95 


\section{Applicability of the proposed method}

In order to test the analytical validity of this approach, the proposed method was applied to the determination of clonazepam in pharmaceutical formulations and human serum using the direct calibration curve. They were treated as described in the Experimental section.

\section{DISCUSSION}

The developed method under the optimal reaction conditions $\left(c_{R(\mathrm{NO}) \mathrm{OH}}=1.4 \times 10^{-5} \mathrm{~mol}\right.$ $\mathrm{L}^{-1}, c_{\mathrm{NaOH}}=8.0 \times 10^{-2} \mathrm{~mol} \mathrm{~L}^{-1}, c_{\mathrm{Co}(I I)}=3.1 \times 10^{-5}$ mol $\left.\mathrm{L}^{-1}, \quad \mathrm{t}=22.00 \pm 0.02{ }^{\circ} \mathrm{C}\right)$ showed statisfactory standard deviation, relative standard deviation (from 3.39 to $1.53 \%$ ) and mean percent recoveries (from $103.12 \%$ to $97.32 \%)$. The least-squares regression analysis used to evaluate the concentration range data indicate linearity over the interval studied $\left(0.32-4.1 \mathrm{mg} \mathrm{mL}^{-1}\right)$. The correlation coefficient obtained for this clonazepam concentration range was 0.9985 . The low value of variance $\left(1.3 \times 10^{-5} \mathrm{\mu g}^{2} \mathrm{~mL}^{-2}\right)$ indicate negligible scattering of the experimental data points around the line of regression. The LOD value of $0.24 \mu \mathrm{g} \mathrm{mL}^{-1}$ indicate that the method is sensitive.

Table 3: Tolerance ratio for foreign species in the determination of $2.21 \mu \mathrm{g} \mathrm{mL}^{-1}$ of clonazepam

\begin{tabular}{|c|c|c|}
\hline Foreign species & $\begin{array}{l}I^{(*)} \\
(\%)\end{array}$ & $\begin{array}{l}\text { Tolerance level } \\
\left(\mu \mathrm{gL}^{-1} \text { interferent } /\right. \\
\left.\mu \mathrm{g} \mathrm{mL}^{-1} \mathrm{CZP}\right)\end{array}$ \\
\hline $\begin{array}{l}\text { citric acid } \\
\text { fructose, glucose, lactose, } B_{1}, B_{6}, B_{12}, F \\
\text { mannitol, sorbitol }\end{array}$ & $\begin{array}{l}10-15 \\
5-10 \\
<5\end{array}$ & $10^{2(n)}$ \\
\hline $\begin{array}{l}\mathrm{Li}^{+}, \mathrm{K}^{+}, \mathrm{F}^{-} \text {, stearic acid } \\
\mathrm{Ca}^{2+}, \mathrm{Mg}^{2+}, \mathrm{Zn}^{2+}, \mathrm{C}_{2} \mathrm{O}_{4}{ }^{2-} \\
\text { Met, Tyr, Trp, Phe, Asp, Ala, Ser }\end{array}$ & $\begin{array}{l}5-10 \\
<5\end{array}$ & 10 \\
\hline His, Arg, Lys, Gly & interference & 1 \\
\hline $\mathrm{Fe}^{3+\left({ }^{(* *)}\right)}, \mathrm{Cu}^{2+}$ & interference & 1 \\
\hline
\end{tabular}

Table 4: Determination of clonazepam in commercial tablet formulation by the proposed method (kinetic) and HPLC methods

\begin{tabular}{|c|c|c|c|c|c|c|c|}
\hline $\begin{array}{c}\text { Pharmaceutical } \\
\text { Preparation }\end{array}$ & $\begin{array}{c}\text { Taken } \\
(\mu \mathrm{g} \\
\left.\mathrm{mL}^{-1}\right)\end{array}$ & $\begin{array}{l}\text { CZP found } \\
\text { by the } \\
\text { proposed } \\
\text { method }^{(*)} \\
\bar{x} \pm \overline{S D}(\mu \mathrm{g} \\
\left.\mathrm{mL}^{-1}\right)\end{array}$ & $\begin{array}{c}\operatorname{RSD}^{(*)} \\
(\%)\end{array}$ & $\begin{array}{c}\text { Recovery }{ }^{(*)} \\
(\%)\end{array}$ & $\begin{array}{c}\operatorname{HPLC}^{(*)} \\
\overline{\left.\mathrm{mL}^{-1}\right)} \\
\overline{S D}(\mu \mathrm{g}\end{array}$ & $\begin{array}{c}\text { F- } \\
\text { value }^{(\star *)}\end{array}$ & value $^{\text {t- }}{ }^{(* *)}$ \\
\hline Rivotril $^{\left({ }^{\prime \prime \prime}\right)}$ & 2.84 & $2.81 \pm 0.04$ & 1.56 & 98.94 & $2.78 \pm 0.03$ & 1.75 & 1.216 \\
\hline Rivotril $^{(* * *)}$ & 3.47 & $3.44 \pm 0.05$ & 1.44 & 99.13 & $3.41 \pm 0.04$ & 1.68 & 1.078 \\
\hline
\end{tabular}


Table 5: Determination of clonazepam in human serum ("Lytorol N) by standard addition method

\begin{tabular}{|c|c|c|c|c|c|c|}
\hline \multicolumn{2}{|c|}{$\begin{array}{l}\text { Proposed method } \\
\left(\mu \mathrm{gL} \mathrm{m}^{-1}\right)\end{array}$} & \multirow{2}{*}{$\begin{array}{c}\operatorname{RSD}^{(*)} \\
(\%)\end{array}$} & \multirow{2}{*}{$\begin{array}{c}\text { Recovery }{ }^{(*)} \\
(\%)\end{array}$} & \multirow{2}{*}{$\begin{array}{c}\frac{\mathrm{HPLC}^{\mathrm{a})}}{\bar{x} \pm \overline{S D}} \\
\left(\mu \mathrm{g} \mathrm{mL}^{-1}\right)\end{array}$} & \multirow{2}{*}{$\begin{array}{c}\text { F- } \\
\text { value }^{(* *)}\end{array}$} & \multirow{2}{*}{$\begin{array}{l}\mathrm{t}- \\
\text { value }^{(* *)}\end{array}$} \\
\hline Added & $\begin{array}{l}\text { Found }^{\left({ }^{()}\right)} \\
\bar{x} \pm \overline{S D}\end{array}$ & & & & & \\
\hline 0.32 & $0.30 \pm 0.02$ & 4.88 & 93.75 & $0.28 \pm 0.01$ & 1.26 & 1.976 \\
\hline 0.95 & $0.92 \pm 0.03$ & 2.34 & 96.84 & $0.91 \pm 0.02$ & 1.91 & 1.090 \\
\hline
\end{tabular}

The ability to predict changes in the rate of the reaction is based on a knowladge of the value of the activation energy. According to Hammond [17] and Smith [18], most reactions which have observable rates at ordinary temperatures have activation energies of $15-30 \mathrm{kcal} \mathrm{mol}^{-1}(62.76-125.52$ $\left.\mathrm{kJ} \mathrm{mol}^{-1}\right)$. A value of $92.45 \mathrm{~kJ} \mathrm{~mol}^{-1}$ obtained in this study, according to this postulate, indicates that the reaction is feasible.

The presence of the usual powdery excipients (fructose, glucose, and lactose) and some amino acids (Met, Tyr, Trp, Phe, Asp, Ala, Ser) did not interfere with the method, The amounts of these additives used are usually much higher than those present in pharamceuticals and human serum. It should also be noted that a higher tolerance level to the presence of vitamins $B_{1}, B_{6}$ and $B_{12}$ existed. Ions, namely, $\mathrm{Ca}^{2+}, \mathrm{Mg}^{2+}, \mathrm{Zn}^{2+}$ and $\mathrm{C}_{2} \mathrm{O}_{4}{ }^{2-}$, interfered when present in approximately 10 -fold in excess. Some amino acids (His, Arg, Lys, Gly) interfered with the method. More severe intrference was observed for $\mathrm{Fe}^{3+}$ and $\mathrm{Cu}^{2+}$ ions. No interference was found when up to 100 -fold mannitol, sorbitol, stearic acid, citric acid and $\mathrm{Li}^{+}, \mathrm{K}^{+}$and $\mathrm{F}^{-}$ions were included.

As can be seen in Table 4, the results obtained by this method are in accordance with the HPLC method. Also, good recovery was observed in the case of serum sample (Table 5), indicating that the constituents of the human serum do not interfere, $\mathrm{Fe}^{3+}$ ions were masked with $\mathrm{F}^{-}$and the protein was precipitated, in any case, with the detection of clonazepam.

The results of the proposed method were statistically compared with those of the HPLC method using a point hypothesis test. Statistical analysis of the results (Tables 4 and 5) showed that calculated F- and t-values at $95 \%$ confidence levels were less than the theoretical ones, confirming no significant differences between the performance of the proposed and the HPLC method. Therefore, the proposed method could be used for the determination of clonazepam in pharmaceutical preparations and serum samples.

\section{CONCLUSION}

The proposed kinetic-spectrophotometric method for the determination of CZP in pharmaceutical samples and human serum reported in this work is simple, rapid, inexpensive, and thus appropriate for routine quality control analyses of the active drug in the laboratories of hospitals, pharmaceutical industries and research institutions. It should also be suitable for developing countries. The validation of the method shows that the results obtained are in good agreement with the reference (HLPC) method.

\section{ACKNOWLEDGEMENT}

This research was supported by grant number 142015 from the Serbian Ministry of Science and Environmental Protection. The 
authors are grateful for the financial support provided by this Ministry.

\section{REFERENCES}

1. Dahlin MG, Amark PE, Nergardh AR. Reduction of seizures with low-dose clonazepam in children with epilepsy. Pediatr Neurol 2003; 28(1): 4852

2. The British Pharmacopoeia 98/34/EEC. London: The Stationery Office, 2005

3. United States Pharmacopoeia, USP-27/NF-22. Rockville: Authority of the United States Pharmacopeia Convention, 2004

4. El-Brashy A, Aly FA, Belal F. Determination of 1,4Benzodiazepines in drug dosage forms by difference spectrophotometry. Microchim Acta 1993; 110(1-3): 55-60

5. Salem AA, Barsoum BN, Izake EL. Determination of bromazepam and clonazepam in pure and pharmaceutical dosage forms using chloranil as a charge transfer complexing agent. Anal Lett 2002; 35(10): 1631-1648

6. Salem $A A$, Barsoum $B N$, lzake $E L$. Spectrophotometric and fluorimetric determination of diazepam, bromazepam and clonazepam in pharmaceutical and urine samples. Spectrochim Acta, Part A 2004; 60(4): 771-780

7. Nie L, Liu D, Yao S. Potentiometric determination of diazepam with a diazepam ion-selective electrode. J Pharm Biomed Anal 1990; 8(4): 379-383

8. Salem AA, Barsoum BN, Izake EL. Potentiometric determination of diazepam, bromazepam and clonazepam using solid contact ion-selective electrodes. Anal Chim Acta 2003; 498(1-2): 79-91

9. Correia dos Santos MM, Famila V, Simoes Goncalves $M L$. Square-wave voltammetric techniques for determination of psychoactive 1,4benzodiazepine drugs. Anal Bioanal Chem 2002; 374(6): 1074-1081
10. Wilhelm M, Battista HJ, Obendorf D. Selective and sensitive assay for the determination of benzodiazepines by high-performance liquid chromatography with simultaneous ultraviolet and reductive electrochemical detection at the hanging mercuty drop electrode. J Chromatogr A 2000; 897(1-2): 215-225

11. Cavedal LE, Mendes FD, Domingues CC, Patni AK, Monif T, Reyar S, Pereira AS, Mendes GD, De Nucci G. Clonazepam quantification in human plasma by high-performance liquid chromatography coupled with electrospray tandem mass spectrometry in a bioequivalence study. J Mass Spectrom 2007; 42(1): $81-88$

12. Gandhi SV, Dhavale ND, Jadhav VZ, Sabnis SS. Spectrophotometric and reversed-phase highperformance liquid chromatographic methods for simultaneous determination of escitalopram oxalate and clonazepam in combined tablet dosage form. J AOAC Int 2008; 91(1): 33-38

13. Pujadas M, Pichini S, Civit E, Santamarina E, Perez $K$, De la Torre R. A simple reliable procedure for the determination of psychoactive drugs in oral fluid by gas chromatography-mass spectrometry. J Pharm Biomed Anal 2007; 44(2): 594-601

14. Gajewska M, Goldnik A, Wojcik E, Lukasik E. Preparation and assay of complex compounds of 1,4-benzodiazepines with metals. Chem Anality 1988; 33(1): 155-162

15. Miller JN. Basic statistical methods for analytical chemistry. Part 2. Calibration and regression methods. Analyst 1991; 116(1): 3-14

16. Ermer J. Validation in pharmaceutical analysis. Part I: An integrated approach. J Pharm Biomed Anal 2001; 24(5-6): 755-767

17. Hammond GS. A correlation of reaction rate. J Am Chem Soc 1955; 77(2): 334-338

18. Smith IWM. The temperature-dependence of elementary reaction rates: beyond Arrhenius. Chem Soc Rev 2008; 37(4): 812-826 